\title{
Les Salafistes and a French Reproduction of Certainties in a World of Uncertainties
}

\author{
Emin Poljarevic
}

\begin{abstract}
The new French documentary Les Salafistes (The Salafis) that premiered January 26, 2016, in a small number of French theaters offers iconographic imagery seldom seen in the public space: a string of interviews with some of the leading jihadist militants in Mali, Tunisia, Algeria, and Iraq coupled with ghastly images of violence perpetrated by militant groups. The intention appears to be to show the irrationality of and paradox in the jihadis' discourse and actions. Unfortunately, the directors have succeeded only in reproducing already existing stereotypes of Salafis. The lack of any appropriate contextualization that problematizes the recent rise of violence in the Middle East and North Africa (MENA) region is perhaps the film's major flaw. Despite the directors' ambition to let violent extremists discredit their own project, the documentary presents an essentialist argument that reproduces Orientalist imageries of a savage religion. Without the appropriate commentary and background overview to the conflicts featured in the film, the audiences are left alone with an extremist narrative that confirms the evocations of the West's moral, cultural, and political superiority over the East.
\end{abstract}

Keywords: Salafis, documentary, jihadis, Mali, Tuaregh

\section{The Documentary}

The genre of non-fictional film productions, otherwise known as documentaries, is cinematic storytelling designed to aesthetically engage and direct audiences. ${ }^{1}$ Les Salafistes, the recently produced French documentary about jihadi groups between February 2012 and July 2015, fits that general definition rather well. ${ }^{2}$ The directors of this biopic, Mauritanian journalist Lemine Ould Salem and French film producer François Margolin, both have had previous experience with covering violence in Muslim-majority contexts. In Les Salafistes,

Emin Poljarevic is a sociologist currently working as a research fellow at Qatar University. He has taught Islamology at Stockholm University, political Islam at Uppsala University, research methodology at the University of Edinburgh, and the history of Islamist movements at Copenhagen University. Several of his publications have surveyed the dynamic of Salafi mobilization in both Muslim minority and majority contexts. 
they present a 71-minute audiovisual description that incorporates monologues by known leaders of several jihadi groups and a wide range of repugnant images that explicate some of the violence committed by them.

The focal point rests, in part, on the cities and administrative regions of Gao and Timbuktu, both of which have been at the center of the Malian civil war and have experienced the rule of militant Salafi groups (ca. July 2012January 2013). Additional recordings originate predominantly from the Iraqi battlefields and Islamic State propaganda videos. The directors' expressed intention is to allow a number of militant Salafi advocates to explain their goals and, at the same time, show how implementing them affects local populations primarily in northern Mali, but also elsewhere, most notably in Iraq, Algeria, Mauritania, and Tunisia.

The directors weave together the militants' rhetoric of how they are establishing justice through the divinely ordained mandate and their seemingly indiscriminate acts of callous violence. ${ }^{3}$ Nevertheless, one of the documentary's most remarkable features is the lack of the overlaid commentary that usually accom- panies such productions. ${ }^{4}$ Here we can see how selected spiritual and military leaders summarize their worldview, the intentions driving their actions, and the religious justifications underlying their various campaigns to establish the "righteous" society under "the rule of Sharia." All of their rhetoric, however, is left largely unproblematized and uncontextualized. In effect, the central message to the French secular audiences seems to be that there is an interminable chasm between their worldview and that of the jihadi militants, for we are left with a feeling that there cannot be any reconciliation between liberal values and those of the jihadis. And that may very well be the case.

However, this portrayal leaves us in an aporia between the multifarious motivations behind jihadi violence, the political context in which it occurs, and common Islamophobic clichés. We are left wondering about the underlying factors. For example, is religious zealotry the key element of violence? Religious extremists have been around for centuries, so why are they only now able to gain traction in such wide areas of the Middle East and North Africa (MENA) region and in such a significant way? These or similar questions are never asked. The trouble here is the overwhelming ambiguity with which the audience is left in terms of identifying or assuming the source(s) of violence in the region featured. Even though the producers' expressed intention is not to reduce Islam or even Salafism to the usual stereotype of a monolithic violent religion, the film suffers greatly from their own epistemological bias: French identity and culture represent the dominant designatum by which all other phenomena are measured and, therefore, judged. This is deeply problematic for several reasons. 
The directors' decision to show a contextually disparate number of violent video sequences and interviews reflects both their desire to reveal how the "enemy" rationalizes its brutality and to confirm Europe's moral superiority over the other, or at least over its violent component. ${ }^{5}$ Yet this production is even more controversial than that, for the choice to omit a superimposed explanatory narrative provoked the French Ministry of Interior to describe Les Salafistes as "dangerous" and Fleur Pellerin, the Minister of Culture, to label it PG-18. ${ }^{6}$ This decision to protect French youth from any possibility of succumbing to radicalization or even of validating jihadi violence has, in turn, provoked a public debate revolving around the government's questionable ruling to censor the documentary, apparently something it has not done since the 1960s. ${ }^{7}$ Moreover, the film's original release date, November 2015, was changed to January 26, 2016, due to the mass shootings in Paris on November $13,2015 .{ }^{8}$ Such a string of decisions deserves a discussion of its own, but for now we focus on the documentary's structure.

\section{Data in a Contextual Void}

Salem and Margolin's choice to edit the wide range of video material from various MENA societies, accompanied by the original sound bites, and present it with no overlaid explanatory commentary is rather uncommon, aesthetically daring, and politically provocative. But it is also something more than that. ${ }^{9}$ Their attempt to let the "data speak" is lopsided and illusive. This type of observational iconographic method attempts to capture organic facts that are alive and moving, which, in turn, provoke emotional responses. ${ }^{10}$ In other words, the specific intention of showing graphic images and rhetorical symbols (of presumably an extreme religion) is to entice abhorrence and, most importantly, fear. The ambition is perhaps to represent reality in a more concentrated way than the dispersed images of extremism that we are already aware of, as if to reveal "what really matters." 11

After all, Salem and Margolin develop their videography on the jihadi narrative's apparent inconsistency, inhumanity, and incoherence, and this is consequently reflected in the negative experiences of the populations they rule. This cinematic narrative is a blunt show of not only the apparent disconnect between jihadi claims to dispense divinely ordered justice and the professed injustice and suffering caused by their rule, but also of the irrationality of Salafism and the subsequent rationality of the French. ${ }^{12}$

The initial impression is that the documentary works on the idea of uncovering the other's nauseating perception of reality, by which a presumably 
francophone audience can reaffirm its superior sense of civilized humanity. This is yet another manifestation of the Muslim other.

Despite all of the directors' well-intended aims and purposes, this effort is yet another manifestation of the Muslim other. It works on the idea of uncovering the other's nauseating perception of reality, by which a francophone audience can reaffirm its superior sense of civilized humanity. How is this done? First, the reductionist tone in terms of what Salafism is and how it allegedly programs its proponents with the irreconcilable desire to destroy all opposition percolates throughout the documentary's 71 minutes. One can therefore reasonably assume that the jihadi group's justificatory narrative and brutality have by now been well-documented by both outside researchers and the jihadis themselves. ${ }^{13}$ But as will become clearer below, the Salafi universe is far more diverse and vibrant than the featured jihadi groups.

Second, the decontextualized presentation of the conflicts from which these groups draw their strength fails to communicate the environment out of which they have emerged. Elaborating upon those important sociopolitical components that are unique to each conflict zone is certainly relevant if we are to enrich our understanding of jihadism in general and of Salafism more specifically. After all, this was one of the directors' explicit aims.

The underlying tension among the content, the lack of contextualization, and the sense of unfulfilled expectations create more incomprehensibility and wonder than understanding. For example, the now well-established tripartite division of Salafi groups into pietists, political activists, and jihadis contradicts the documentary's all-inclusive and definitive title. ${ }^{14}$ The component that these groups share is not just the name, for all of them have the same ambition: to purify their fellow Muslims' beliefs and practices from what they consider to be "heresies." Any attempt to radically reform the religious and sociopolitical status quo anywhere inevitably creates tensions. This is especially true when opposing civil society organizations work in the opposite direction.

In the MENA region's increasingly fragmented Islamicate societies, the matter is complicated further when many regimes vehemently oppose the mobilization of Salafi groups or, for that matter, that of any civil society group beyond its control. Nonetheless, the puritan streak of Salafi activism is a modern phenomenon that has to do with the desire of religious conservative purists to unshackle traditionally Muslim-majority societies from that they perceive as immoral influences. It represents a utopian desire to reconstruct "authentic" Islam, where the text is the criterion for organizing the society. ${ }^{15}$

The film's very structure supports the above assumption. For instance, a viewer has little choice but to accept the jihadi narrative that Salafism represents the "pure" form of Islam and, for that reason, is reminiscent of the other's 
violent predisposition. However, this not so subliminal notion is contradicted by the existence of a far greater number of Salafis who are possibly just as zealous supporters of the idea of religious purity, but who reject violence as a tool for social reform and religious revival. ${ }^{16}$ In other words, while jihadis generally consider violence as a pivotal part their activism, Salafi pietists and political activists exclude violent action as a legitimate strategy to reorganize Islamicate societies.

Salafists can be considered to be a part of an intensely value conservative stream of broader Islamicate politics. This stream is as ideologically and strategically diverse as any other political combination located on the traditional left-to-right political spectrum. As with any political (and religious) movement, the focus here is to identify those who share the Salafis' "authentic" Islamic faith and practice. This verification of authenticity is supposed to assure a person's "correct" identity by making her or him not only morally responsible but also spiritually pure, as opposed to all others. Be that as it may, in recent decades these groups have developed a range of mobilization strategies based on the notion of "authentic" identity in their attempt to bring into being a social order based upon their individual literalist interpretations of the Islamic canon. ${ }^{17}$

Objectionable as this may appear to European and American audiences, Salafi groups are now a noticeable part of the Islamicate public sphere. This heterogeneous conservative element of the MENA's political and ideological landscape, along with all of its illiberal features, cannot be dismissed as irrational and inherently violent. And yet Les Salafistes suggests that Salafis en masse are just that. By extension, and even more troubling, it intuitively suggests that French Salafis are a mirror image of this "evil." Such an innuendo does not reflect the complexities on the ground in France or elsewhere. ${ }^{18}$ Still, the threat of jihadi violence and its actual destruction should not be underestimated, glossed over as irrelevant, or, for that matter, as negligible. Rather, it ought to be contextualized, problematized, and linked to the historical, political, social, and economic circumstances if we expect to understand this type of violence. Salem and Margolin fail to address any these dimensions.

This serious flaw becomes even more apparent if we consider that our historical knowledge is contingent upon a potentially countless number of variables, not the least of which are the social relations in the places in which we grew up, which school system we attended, and how we have been shaped by our many experiences. ${ }^{19}$ As our perception of social reality is heavily colored by those experiences, our generalizations, classifications, and cognitions of reality are all but predestined by the things we "know." This is especially true of our subjective knowledge as regards our own or distant religions, cul- 
tures, and societies. Regardless of this awareness, we seem to continuously seek unitary explanations to complex realities. For instance, the radicalization process of Charlie Hebdo gunmen Saïd and Chérif Kouachi has been neither straightforward nor ideologically predetermined. The process and its deadly aftereffect have been perforated by their predominantly negative sociopolitical, cultural, and religious experiences - all of which led to one out of many possible outcomes. ${ }^{20}$

One needs to look for an answer to the following question: Is there a connection between jihadi violence in France and the sociopolitical context of the places featured in Salem and Margolin's documentary? Although any such answer is well beyond the scope of this article, one can nevertheless reasonably assume that modern French history, dominated as it is by colonial conquests, is very entangled with the destructive events taking place in the MENA region. ${ }^{21}$ The convolution of French domestic policies regarding its Muslim minorities in the past decades have all but revealed the deep-seated colonial attitude toward its African, Arab, and Muslim minorities. ${ }^{22}$

\section{A Closer Look at Mali}

By way of contextualizing some of the scenes presented, we could consider the fact that the multicultural Malian society has experienced four waves of civil conflict in its short post-colonial existence: 1963, 1991, 2006, and 2012. The latest wave of ethnic violence between the northern Tuaregh (Amazigh) and Arab tribes and the southern Mande (e.g., Bambara and Malinke) and Fula tribes is just one of the many consequences of the ongoing French (neo)colonial presence in the region. ${ }^{23}$ The southerners' political dominance has been a traditional source of grievance for the northern populations, a reality that, in turn, has encouraged the long-simmering idea of Azawad (northern Mali) independence. ${ }^{24}$ The string of events that unleashed the most recent wave of violence was triggered by the March 22, 2012, military coup d'état that deposed the elected president Amadou Toumani Touré. Within a week, and amid political chaos in the capital city of Bamako, the leadership of the Tuaregh nationalist rebel movement in the north, Mouvement national de libération de l'Azawad (MNLA), ${ }^{25}$ together with the predominantly Tuaregh jihadi organization Ansar Dine, had captured most of the major northern cities, most significant among them Gao and Timbuktu. ${ }^{26}$

The uneasy alliance between the nationalist MNLA and the jihadist Ansar Dine was tested by the declaration of "Sharia rule" in the north (predominantly in Gao), which lasted from July 2012 to January 2013, ended due to French military involvement. The string of events was further complicated by the ar- 
rival of al-Qaida in the Islamic Maghreb (AQIM) and its splinter group Mouvement pour l'unicité et le jihad en Afrique de l'Ouest (MUJAO) ${ }^{27}$ and, later on, by the hybrid group al-Murabitun. ${ }^{28}$ This latter group, which consists of MUJAO and al-Mulathamin, ${ }^{29}$ is predominantly comprised of regional outsiders who are clearly unsympathetic to the MNLA's nationalist cause.

Thanks to the turn of events caused primarily by the French military intervention, the MNLA rebels gained credence as a politically recognized representative of the non-jihadist northern rebels, who are recognized as a legitimate political power broker. As such, the MNLA can negotiate the terms of a ceasefire with the Bamako government. The reduced jihadist groups, excluded from any attempted negotiations and driven into Mali's northern border regions, have no role in any political negotiations. ${ }^{30}$ The stream of events and multitude of conflict interlocutors - religious, nationalist, and secular - indicates the interplay of complex political and social interests on the national, regional, and international levels.

Take, for instance, Ansar Dine's founder and leader Iyad ag Ghali, a native of the northern city of Kidal. This member of the Tuaregh political elite (Ifogha clan) had been a leader of the Azawad Popular Movement in the 1990s. During this period, his religious conservatism had not been in the way of his nationalist cause. In the 2000s he became internationally recognized for his role in the peace negotiations between the MNLA (and other Tuaregh groups) and Bamako during the 2006 uprising. ${ }^{31}$ In the aftermath of the Algerian-sponsored settlement, new rebel groups emerged due to their dissatisfaction with the implementation of the peace accords as well as with Bamako's failure to address the many infrastructural problems in northern Mali.

In the meantime, the formation of the transnational organization AQIM and the kidnaping business in the region, the popular uprising in Libya in February 2011, and the subsequent fall of the Qaddafi regime that August all magnified the seriousness of the Malian civil conflict. The returning Tuaregh legionaries from Libya and an increased inflow of arms complicated the security situation even further. Amid the turmoil, the ambitious Iyad ag Ghali utilized his political capital to amass support among disgruntled Tuaregh rebels and founded Ansar Dine in early 2012. ${ }^{32}$

This all goes to show that an analysis of Salafism in Mali or, for that matter, any religious-political-social movement anywhere should include a wider set of parameters so that the public can acquire a better grasp of the causes behind some of the violence committed by such groups. It is naïve to believe that "allowing" the leaders of violent groups to declare their ideological agenda will somehow reveal the facts behind their mobilization strategies. Relatedly, are we ready to believe former President George W. Bush's justifications for the 
American-led invasion and subsequent occupation of Iraq as being necessary due to the "facts" that Saddam Hussein possessed and produced biochemical weapons and had "given shelter and support to terrorism" or the freedom argument, "People everywhere prefer freedom to slavery; prosperity to squalor; self-government to the rule of terror and torture," by which to justify war? ${ }^{33}$ Such media theatrics that have a real potential to incite violence and hatred need to be problematized, critically analyzed, and contextualized, especially in our contemporary hyperconnected and interactive media-dominated world. ${ }^{34}$ This is critically important in the light of the de facto disintegration of the Iraqi state and the intensified sectarian conflicts in the region.

\section{Conclusion}

The perception of reality, rather than the observable facts on the ground, has frequently shaped our understanding of the world. ${ }^{35}$ Despite their ambition to let the "enemy" speak through an engaging and innovative presentation technique, the directors of Les Salafistes, Salem and Margolin, have done no more than reproduce the essentialist argument about Salafis that is already embedded in the French public discourse. ${ }^{36}$ Their approach makes it pretty clear that providing simple explanations to a complex set of problems, such as the rise of jihadism and youth radicalization, are usually wrong. Religious doctrines seem rarely, if ever, to be the triggers of violence per se. ${ }^{37}$

In fact, these doctrines serve mostly as mental pictograms that simplify both the harsh realities surrounding a particular individual and offer solutions to such realities. It is, therefore, reasonable to assume that religious extremists' narratives, much like those of various right-wing nationalists, are expressed frustrations and simple solutions to a multiple complex issues that surround them. This means that empirically rooted explanations of these complex issues are at the disadvantage when opposed by simplistic testimonies and religious and political slogans, especially if we, the audience, are already preconditioned to believe in simple "truths."

\section{Endnotes}

1. Bill Nichols, Introduction to Documentary (Bloomington: Indiana University Press, 2001); Shilo T. McClean, Digital Storytelling: The Narrative Power of Visual Effects in Film (Cambridge, MA.: The MIT Press, 2007).

2. The documentary is a Margo Cinema production, in conjunction with France 3 Cinéma, Canal + and France Télévisions, http://www.imarabe.org/cinema/ salafistes.

3. Mathilde Blottière, "L'interdiction de "Salafistes" aux moins de 18 ans confirmée par Fleur Pellerin" ("Fleur Pellerin confirms the 18 years limit for 
'Salafis"'), Telerama, 27 Jan. 2016, www.telerama.fr/cinema/salafistes-avecune-interdiction-aux-moins-de-18-ans-le-film-est-enterre,137323.php.

4. The documentary that precedes and captures the regional complexities more effectively is Timbuktu. See Anthony O. Scott, “A Fury Arrives. Hypocrisy, Too. Timbuktu," The New York Times, 28 Jan. 2015, www.nytimes.com/2015/ 01/28/movies/timbuktu-an-abderrahmane-sissako-film-about-radicalislam.html?_r=0.

5. Magolin reportedly said: "People are intelligent enough to understand the contrast" between the propaganda images and the practice of how their ideas work. Lilia Blaise, "France Restricts 'Salafistes,' Film on Islamic Radicals,” The New York Times, 27 Jan. 2016, www.nytimes.com/2016/01/28/world/europe/francerestricts-salafistes-film-on-islamic-radicals.html? r=0. For similar statements, see Par Jean-Louis Le Touzet, Didier Péron, and Emmanuel Fansten, "'Salafistes', l'aversion originale" (Salafis, the original aversion), 25 Jan. 2016, www.liberation.fr/france/2016/01/25/salafistes-l-aversion-originale_1428926.

6. Blottière, "L'interdiction de 'Salafistes."

7. Emmanuelle Jardonnet, "Retraités et étudiants curieux à la première séance de 'Salafistes,"' (Curious retired elders and students at the premiere viewing of 'Salafis"'), Le Monde, 28 Jan. 2016, http:/www.lemonde.fr/cinema/article/ 2016/ 01/28/retraites-et-etudiants-curieux-a-la-premiere-seance-de-salafistes 4855018_3476.html. See also Natalie Nougayrède, "Les Salafistes is gruelling viewing - but it can help us understand terror," The Guardian, 30 Jan. 2016,www. theguardian.com/commentisfree/2016/jan/30/jihadi-film-les-salafistes-documentary-france-twisted-ideology.

8. Olivier Milot, "France 3 ne diffusera pas 'Salafistes' dans le 'contexte actuel,", Telerama, Jan. 26, 2016, television.telerama.fr/television/france-3-ne-diffuserapas-salafistes-dans-le-contexte-actuel,137493.php.

9. This style of filming is described as "observational," meaning that the filmmaker's emphasis is to engage the public with the recorded images without providing any authoritative commentary. See Nichols, Introduction to Documentary.

10. Thomas Mitchell, Iconology: Image, Text, Ideology (Chicago: University of Chicago Press, 1986), 179-85; Gillian Rose, Visual Methodologies: An Introduction to Researching with Visual Materials (London: Sage Publications Ltd., 2012).

11. Jean Baudrillard, Simulacra and Simulation, trans. Sheila Faria Glaser (Ann Arbor: Michigan University Press, 1995), 6-10.

12. Elise Maillard, "Salafistes: 'On a risqué notre vie pour montrer ce que pensent ces gens',” BFM TV, Jan. 26, 2016, www.bfmtv.com/societe/salafistes-on-arisque-notre-vie-pour-montrer-ce-que-pensent-ces-gens-946644.html.

13. See Islamic State's prime publication in English, Dabiq magazine, on the Calrion Project at website: http://www.clarionproject.org/news/islamic-state-isis-isilpropaganda-magazine-dabiq.

14. Quintan Wiktorowicz, "Anatomy of the Salafi Movement," Studies in Conflict \& Terrorism 29 (2006): 207-39; Emin Poljarevic, "The Power of Elective Affinities in Contemporary Salafism," The Muslim World 106, no. 3 (forthcoming). 
15. Emin Poljarevic, "In Pursuit of Authenticity: Becoming a Salafi," Comparative Islamic Studies 8, nos. 1-2 (2012).

16. A pietist Salafi website: SalafiActu: https://salafiactu.wordpress.com/category/ sectes/.

17. See Roel Meijer, ed., Global Salafism: Islam's New Religious Movement (New York: Colombia University Press, 2009).

18. Terje T. Østebø," Local Reformers and the Search for Change: The Emergence of Salafism in Bale, Ethiopia," Africa 81, no. 4 (2011); Bjørn O. Utvik,"The Ikhwanization of the Salafis: Piety in the Politics of Egypt and Kuwait," Middle East Critique 23, no. 1 (2014): 5-27; Susanne Olsson "Proselytizing Islam Problematizing 'Salafism," The Muslim World 104, nos. 1-2: (2014): 171-97. See also the Salafi activist site SalafiActu: https://salafiactu.wordpress.com/lesmosquees-salafi/.

19. Allan Megill, Historical Knowledge, Historical Error: A Contemporary Guide to Practice (Chicago: Chicago University Press, 2007).

20. John Lichfield, "Paris attacks: Why the Charlie Hebdo gunmen Saïd and Chérif Kouachi made an unlikely terror cell," The Independent, Jan. 18, 2015, www.independent.co.uk/news/world/europe/paris-attacks-why-the-charlie-hebdo-gunmen-sa-d-and-ch-rif-kouachi-made-an-unlikely-terror-cell-9986391.html; Olivier Cyran, “'Charlie Hebdo', pas raciste ? Si vous le dites...” (Charlie Hebdo', not racist? If you say so...), Article 11, December 5, 2013, http:/www.article11.info/? Charlie-Hebdo-pas-raciste-Si-vous\#pagination_page; Serge Quadruppani, "Toucher le Fond - sur Les Attentats Djihadistes des 7, 8 at 9 Janvier à Paris et Leurs Suites," Article 11, Jun. 1, 2015, www.article11.info/?Toucher-le-fond-Surles-attentats; For a more theoretical argument, see Quintan Wiktorowicz, Radical Islam Rising (Lanham, MD: Rowman \& Littlefield Publishers, 2005); Peter R. Neumann, "The Trouble with Radicalization," International Affairs 89, no. 4 (2013): 873-93.

21. See Robert Blanton, David Mason, and Brian Athow, "Colonial Style and PostColonial Ethnic Conflict in Africa," Journal of Peace Research 38, no. 4 (2001): 473-91; Frederick Cooper, "Conflict and Connection: Rethinking Colonial African History," The American Historical Review 99, no. 5 (1994): 1516-45.

22. Andrew Hussey, The French Intifada: The Long War between France and Its Arabs (New York: Faber and Faber Inc., 2014), 27-31.

23. The French colonial presence in Mali initially lasted nearly 150 years (18921960). Add to that its continuous military presence in the region (in Chad) from 1986 to 2014 (Operation Epervier and Operation Serval), and the most recent military intervention in Mali (Operation Berkhane, August 2014-ongoing).

24. See Baz Lecoq, Disputed Desert: Decolonisation, Competing Nationalisms, and Tuareg Rebellions in Northern Mali (Leiden and Boston: Brill, 2010).

25. Movement for the National Liberation of the Azawad.

26. Lawrence E. Clinea, "Nomads, Islamists, and Soldiers: The Struggles for Northern Mali,” Studies in Conflict \& Terrorism 36, no. 8 (2013). See also Baz Lecocq 
and Georg Klute, "Tuareg Separatism in Mali," International Journal 68, no. 3 (September 2013): 424-34; Julius Cavendish, "The Fearsome Tuareg Uprising in Mali: Less Monolithic than Meets the Eye," Bamako content.time.com/ time/world/article/0,8599,2110673,00.html?xid=gonewsedit.

27. Movement for Oneness and Jihad in West Africa.

28. The Protectors.

29. The Masked Ones.

30. For a detailed overview of these events, see Alex Thurston, "Toward an 'Islamic Republic of Mali,"' The Fletcher Forum of World Affairs 37, no. 2 (2013): 4566.

31. Chahana Takiou, "Rébellion au Nord Mali, Comment Iyad Ag Ghali a repris le maquis," Afribone, May 29, 2006, www.afribonemali.net/spip.php?article3693.

32. International Crisis Group, "Mali: Avoiding Escalation," ICG Africa Report No.189 (July 18), http://www.crisisgroup.org/en/regions/africa/west-africa/ mali/189-amali-avoiding-escalation.aspx.

33. George W. Bush, October 8, 2002, "Bush: Don't wait for mushroom cloud" CNN, October 8, 2002, edition.cnn.com/2002/ALLPOLITICS/10/07/bush.transcript/. See also Andrew Calabrese, "Casus Belli: U.S. Media and the Justification of the Iraq War," Television \& New Media 6, no. 2 (2005): 153-75.

34. See Janna Quitney Anderson and Lee Rainie, "Millennials will benefit and suffer due to their hyperconnected lives," Pew Research Center's Internet \& American Life Project, Washington DC: Pew Research Center, 2012), http://s3.amazonaws.com/static.pseupdate.mior.ca/media/links/Future_of_Internet_2012_Young brains_PDF.pdf.

35. In the case of the American citizens' perspective on the possibility of Iraq possessing weapons of mass destruction and its potential to threaten the country's security, see Steven Kull, Clay Ramsay, and Evan Lewis, "Misperceptions, the Media, and the Iraq War," Political Science Quarterly 118, no. 4 (2003): 56998.

36. See Muhamed-Ali Adraoui, "Radical Milieus and Salafis Movements in France: Ideologies, Practices, Relationships with Society and Political Visions," EUI Working Paper, Max Weber Programme: Florence 2014; Martha Nussbaum, The New Religious Intolerance (Cambridge, MA: Harvard University Press, 2012); Doug Sanders, The Myth of the Muslim Tide: Do Immigrants Threaten the West? (New York: Random House, 2012).

37. Scott Atran, "ISIS is a revolution," AEON, Dec. 15, 2015, www.aeon.co/essays/ why-isis-has-the-potential-to-be-a-world-altering-revolution. 